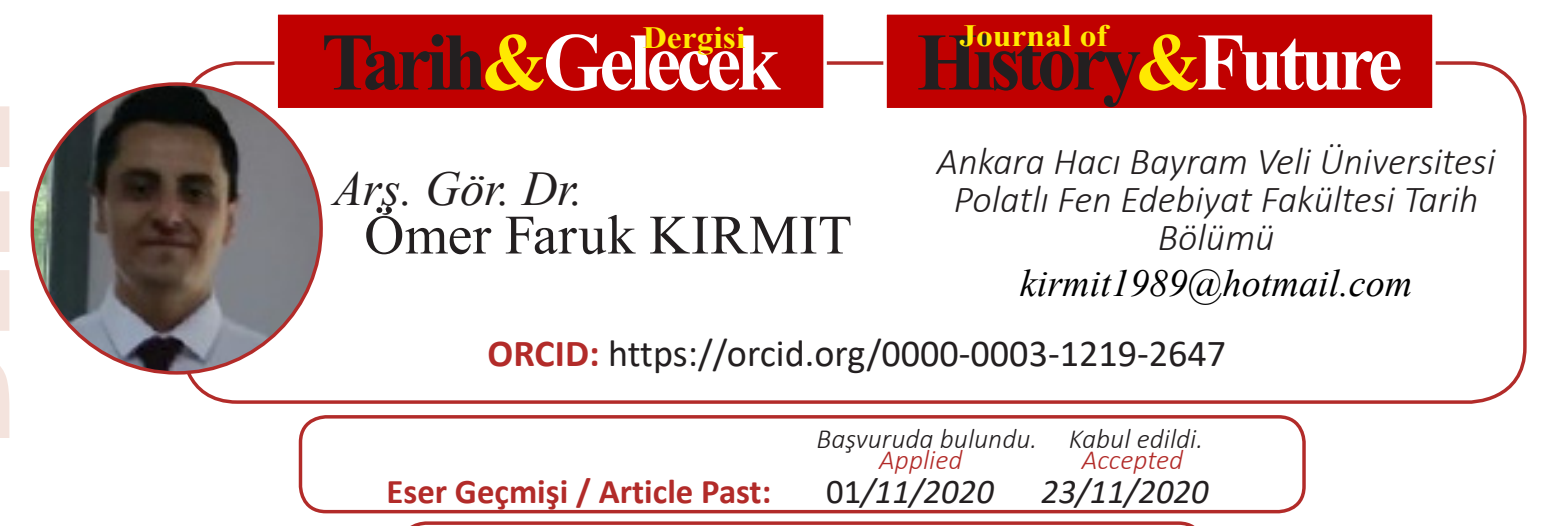

Araştırma Makalesi

DOI: http://dx.doi.org/10.21551/jhf.829454

Research Paper

Orjinal Makale / Orginal Paper

\title{
İzmir'in İşgalinden Sonra Yapılan Büyük Sultan Ahmet Mitingleri
}

\author{
The Great Sultan Ahmet Meetıngs Made after İmir's Occupation
}

\section{$\ddot{O} \mathbf{z}$}

Osmanlı Devleti, 1914-1918 yılları arasında vuku bulan I. Dünya Savaşına İttifak devletleriyle aynı saf içinde katılmıştır. İngiliz ve Fransız kuvvetleri Bulgaristan’ı mağlup edince Osmanlı sınırı olan Trakya'ya kadar gelmişlerdir. Bulgaristan'ın mağlup olmasıyla beraber Osmanlı'nın da Almanya ile olan kara irtibatı kopmuş ve Almanya Osmanlı'ya gereken yardımı yapamamıştır. Ordunun ihtiyaçları için gereken yardımı alamayan Osmanlı, hükmen yenildiğini kabul etmiş ve 30 Ekim 1918 tarihinde Mondros Ateşkes Antlaşmasını imzalayarak savaştan çekilmek zorunda kalmıştır. I. Dünya Savaşının hemen akabinde Mondros Ateşkes Antlaşmasının maddeleri uygulanmaya konulmuş ve Osmanlı topraklarının çeşitli yerlerinde işgaller başlamıştır. Özelikle İzmir' in, 15 Mayıs 1919'da işgal edilmesi halkta büyük bir yankı oluşturmuş ve ülkenin değişik yerlerinde işgallere karşı protesto yürüyüşleri başlatılarak, mitingler düzenlenmiştir. Bu mitinglerin içerisinde Sultan Ahmet meydanında yapılan ve bu isimle anılan mitinglerin önemi çok büyük olmuştur. Bu çalışmanın amacı; İzmir'in işgalinden sonra İstanbul'da halkın bilinçlenmesi amacıyla yapılan büyük Sultan Ahmet mitinglerini anlatmak, bu mitinglerin kamuoyunda, ulusal ve yurtdışı basınında ne gibi etkilerinin olduğunu tespit etmektir. Araştırmanın en önemli kaynağını dönemin gazeteleri oluşturmaktadır. Bunun yanında telif eserler, makaleler, ansiklopedi maddeleri ve tezlerden de faydalanılmıştır.

Anahtar Kelimeler: Mondros Ateşkes Antlaşması, İzmir'in İşgali, Sultan Ahmet Mitingleri, Mustafa Kemal Paşa, Halide Edip Adıvar.

\footnotetext{
Abstract

The Ottoman Empire participated in the First World War, which took place between 19141918, in the same side with the central powers. When the British and French forces defeated Bulgaria, they came to Thrace, which was the Ottoman border. With the defeat of Bulgaria, the Ottoman land 
contact with Germany was severed and Germany could not provide the necessary assistance to the Ottoman Empire. The Ottoman, who could not get the necessary assistance for the needs of the army, accepted that he was defeated by default and had to withdraw from the war by signing the Mondros Armistice on October 30, 1918. Immediately after the First World War, the articles of the Mondros Armistice were put into effect and the occupations began in various parts of the Ottoman lands. Especially with the occupation of Izmir on May 15, 1919, it created a great repercussion in the public and protest marches were started and meetings were held in different parts of the country against the occupations. Among these meetings, the meetings held in Sultan Ahmet Square and named with this name had a great importance. The aim of this study is; It is to explain the great Sultan Ahmet rallies held in Istanbul after the occupation of Izmir to raise awareness of the public, and to determine what effects these rallies had on the public, national and international press. The newspapers of the period constitute the most important source of the research. Besides, copyrights, articles, encyclopedia articles and theses were also used.

Key Words: Mondros Armistice, Occupation of Izmir, Sultan Ahmet Meetings, Mustafa Kemal Paşa, Halide Edip Adıvar.

\section{Giriş}

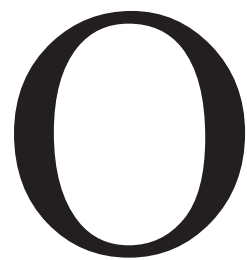

smanlı Devleti, Almanya ile 1800'lü yılların ortasından itibaren ikili ilişkilerini gelişstirmiş ve bu ilişkiler II. Abdülhamit döneminde daha ileriye taşınmıştır. II. Abdülhamit'in tahttan indirilmesinden sonra 1908 yılında devlet yönetimine egemen olan İttihat ve Terakki Partisi döneminde ise Almanya ile ilişkiler daha da sıkı tutulmuş ve özellikle askeri alanda birçok yakın ilişkiler kurulmuştur. Osmanlı Devleti, 8 Ekim 1912 - 10 Ağustos 1913 yılları arasında gerçekleşen Balkan Savaşlarını kaybettiği zaman, ordusunu Alman askeri sistemine göre yenilemek ve modernleştirmek istemiş ve bunun için ise 22 Mayıs 1913 tarihinde Almanya devletine müracaat etmiştir. Bu isteği olumlu karşılayan Almanya, Limon Von Sanders'in başında bulunduğu Alman askeri heyetini Türk ordusunu modernize etmek için Türkiye'ye göndermiştir. ${ }^{1}$ Osmanlı Devleti ile Almanya arasında yaşanan bütün bu gelişmeler, iki devletin I. Dünya Savasında kader birliği etmesinin önünü açmış ve kurulacak olan İttifak bloğunun en güçlü iki devletinin müttefik olarak savaşa girmesi sonucunu ortaya çıkarmıştır. Neticede Osmanlı, 2 Ağustos 1914 yılında Almanya ile bir antlaşma imzalayarak I. Dünya Savaşına Almanya'nın yanında katılmış ve akabinde ise padişah V. Mehmet Reşat bütün Osmanlı ülkesinde genel seferberlik ilan etmiştir. ${ }^{2}$

Böylece Osmanlı Devletinin de dahil olduğu İttifak Devletleri bloğu oluşturulmuş ve devletler içerisinde Almanya, Bulgaristan, Avusturya-Macaristan İmparatorluğu ile Osmanlı

1 Osmanlı Belgelerinde Birinci Dünya Harbi, Başbakanlık Devlet Arşivi Genel Müdürlüğü Yayınları, İstanbul, 2013, s.37.

2 Stanford Shaw, Birinci Dünya Savaşı’nda Osmanlı Imparatorluğu Savaşa Giriş, Türk Tarih Kurumu Yayınları, Ankara, 2013, s.99. Mühlman’a göre; I. Dünya Savaşı öncesi her ne kadar da Osmanlı-Almanya ilişkileri gelişse de, Osmanlı Devleti I. Dünya Savaşının yeni başladığı sırada İttifak Devletlerinin yanında savaşa katılmak için yoğun diploması mücadelesi yürütmüş fakat bu devletler tarafından kabul edilmemiştir. Carl Mühlman, İmparatorluğun Sonu 1914, Timaş Yayınları, İstanbul, 2014, s.59. 
Devleti yer almıştır. İtalyan Devleti de ilk başta İttifak bloğu içerisinde yer almış fakat savaş başladığı zaman saf değiştirerek İtilaf Devletlerinin tarafına geçmiştir. İtilaf Devletlerinin başını İngiltere çekmiştir. Bu ittifaka Fransa ve Rusya'nın da katılmasıyla daha da genişlemiştir. Dört yıl boyunca sürecek olan savaş, her iki bloğunda enerjisini tüketmiş ve büyük maddi kayıpların yanında yetişmiş insan gücünü de önemli ölçüde kaybettirmiştir. Nitekim 15 Eylül 1918'de Bulgaristan'ın Makedonya cephesi Fransız kuvvetleri tarafindan yarılmasıyla, savaşın seyri İttifak kuvvetleri aleyhine değişmiştir. Cephesi yarılan Bulgaristan Devleti artık savaşamayacak duruma gelmiş ve 6 Eylül'de bir mütareke yapılması için İtilaf Devletlerinin temsilcilerine müracaat etmiştir. İtilaf Devletleri, 28 Eylül 1918'de Bulgar Hükümeti bir ateşkes antlaşması imzalamış ve Bulgaristan I. Dünya Savaşından çekildiğini bildirmiştir. ${ }^{3}$ İttifak bloğu içerisinde yer alan devletlerden sadece Bulgaristan'ın değil diğer devletlerinde ordusu perişan bir halde bulunmaktaydı. Bulgaristan'dan sonra ikinci bir ateşkes isteği Almanya'dan gelmiştir. Almanya, 5 Ekim 1918'de ateşkes mütarekesi yapılmasına aracı olması ve haklarını koruyacak bir antlaşma yapılması isteğiyle Amerika temsilcisine başvurmuştur. Bulgaristan ve Almanya'nın savaştan çekilmesiyle, Osmanlı Devleti de Almanya'nın ateşkes müracaatında bulunduğu aynı gün, İspanya'nın aracıllğıyla Amerikan hükümetine ateşkes için müracaat etmiştir. İttifak devletleri içerisinde bulunan Bulgaristan, Almanya ve Osmanlının ateşkes istemesiyle tek başına kalan Avusturya-Macaristan'da, bir ateşkes yapılması isteğiyle Amerika'ya müracaat etmiş̧tir. ${ }^{4}$ Sonuçta İttifak Devletleri mağlup olduklarını kabul ederek I. Dünya Savaşından çekilmişler ve bir ateşkes antlaşması imzalamışlardır. Akabinde ise ası1 antlaşmanın yapılması için beklemeye koyulmuşlardır.

Osmanlı Devleti, yapılacak olan Ateşkes Antlaşmasının şartlarını görüşmek için Bahriye Nazırı Rauf Bey başkanlığındaki bir ekibi, 27 Ekim 1918'de Limni adasında bulunan Mondros limanına göndermiştir. Osmanlı ile İtilaf Devletleri temsilcileri arasında yapılacak olan görüş̧meler, bu limanda bulunan Agememnon zırhlısında başlamıştır. 3 Temmuz 1918'de Osmanlı tahtına oturan padişah VI. Mehmet yani bilinen adıyla Sultan Vahdettin, Mondros Antlaşmasını imzalayacak olan heyete; Osmanlı saltanatının ve hanedanının haklarının korunması-ve bazı Türk olmayan vilâyetlere verilecek olan muhtariyetin, siyasî değil idarî olarak taksim edilmesi gerektiğine dair bir talimat vermişsir. Heyete, kabineyi kuran Ahmet İzzet Paşa hükümeti tarafından da bütün ülkenin geleceğini ilgilendiren asıl bir talimat da verilmiştir. Bu talimatta ülkenin geleceğine yönelik yapılması gereken önemli bilgiler olmakla birlikte, ABD başkanı Wilson'un öne sürdüğü prensiplere de gereğinden fazla umut bağlandığı görülmektedir. Bunlar: 1-Hükümetin devlet yönetimine karışılmaması, 2- Ülke sınırları dahilinde hiçbir yere yabancı asker çıkarılmaması, 3Almanların Osmanlı'ya ettiği yardım sona erdiği için, İtilâf devletlerinin para yardımı yapması, 4- Boğazlar, Yunan gemilerinin geçmemesi şartıyla herkese açık bulundurulabilecek ve oradaki ordu terhis edilebilecektir. ${ }^{5}$

27 Ekimde başlayan görüşmeler üç gün sürmüş ve 30 Ekim 1918'de Mondros Antlaşması imzalanmıştır. ${ }^{6}$ Antlaşma 24 maddeden oluşmuş, en çok tepki çeken ve en tehlikeli maddeleri ise 7.

3

4

5 Cemil Öztürk, "Mondros Mütarekesi”, TDV. İslam Ansiklopedisi, Cilt 30, Diyanet Vakfı Yayınları, İstanbul, 2005, s.271-272; Rahmi Doğanay-Erdal Açıkses, Türkiye Cumhuriyeti Tarihi ve Atatürk Illkeleri, Manas Yayınları, Elazığ, 2006, s. 61-63.

6

Tanin, 30 Eylül 1918.

Vakit, 6,7,8 Ekim 1918.

Selahattin Tansel, Mondros'tan Mudanya'ya Kadar, Cilt I, MEB. Yayınları, İstanbul, 1991, s. 25; Rauf 
ve 24. maddeler olmuştur. 7. Maddede; İtilaf Devletlerine kendi güvenlikleri için tehlikeli gördüğü isteği yeri işgal etme hakkı verirken, 24. maddede ise; Doğu ve Güneydoğu Anadolu Bölgesinde bulunan 'Erzurum, Van, Harput, Diyarbakır, Sivas ve Bitlis'in de dahil olduğu altı vilayette, herhangi bir olay olması veya karışıklık çıkması halinde, İtilâf devletleri bu şehirleri istedikleri zaman işgal edebileceklerdir. İtilaf Devletlerinin, bu iki maddeye dayanarak ve bunu gerekçe göstererek, istedikleri zaman Osmanlı topraklarını işgal edebilmenin önünü açmaya çalıştıkları görülmektedir. ${ }^{7}$ Antlaşma maddeleri Osmanlı'ya siyasi, askeri, sosyo-kültürel ve ekonomik olarak da bir takım olumsuz gelişmelerle karşı karşıya bırakmıştır. Antlaşmanın imzalanmasında bir gün sonra İtilaf Devletleri, 1 Kasım 1918 tarihinden itibaren Osmanlı topraklarını işgal etmeye başlamışlardır. Anadolu'nun hemen hemen her yeri işgal edilmiş ve Mustafa Kemal Atatürk'ün 19 Mayıs 1919’ de Samsun'a çıkmasıyla birlikte yeni bir sürece girilmiştir. ${ }^{8}$

\section{1-İzmir'in Yunan Kuvvetleri Tarafından İşgal Edilmesi}

İtilaf devletleri Mondros Ateşkes Antlaşmasıyla Osmanlı ülkesini işgale başlamışlar ve 18 Ocak 1919 tarihinde ise I. Dünya savaşında mağlup olan devletlerin durumunu görüşmek üzere Paris’te, Paris Barış Konferansı'nı toplamışlardır. Bu toplantıya katılan Yunanistan bir takım sahte nüfus istatistikleri düzenleyerek, içerisinde İzmir'in de bulunduğu Batı Anadolu coğrafyasının kendilerine verilmesini istemiştir. İngiltere delegasyonu başta Yunan isteklerine şiddetle karş1 çıkmış ancak daha sonra Yunanistan'ın isteklerini destekleyecek tarzda tutum takınarak, istedikleri yerlerin verilmesi için bir uzman kurulu oluşturulmasını talep etmiştir. ${ }^{9}$ Paris Barış Konferansında İzmir'e kimin sahip olacağı konusunda sert tartışmaların yapıldığı görülmektedir. Özellikle İtalya da Yunanistan gibi İzmir'i sahiplenmek istemiş ve kendilerine verilmesini talep etmiştir. Fakat İtilaf devletlerinin en güçlü temsilcisi olan İngiltere, İzmir'e İtalyanların değil de Yunanların sahip olmasını istiyordu. Çünkü ilerleyen zamanlarda Doğu Akdeniz'de kendisine rakip olabilecek güçlü bir İtalyan devleti yerine, kendi sözünü dinleyebilecek olan zayıf Yunanistan devletinin burada hakim olması, daha çok işine gelmiştir. İngiltere, o bölgenin ve İzmir'in Yunanistan'a verilmesi için, konferansta elinden geleni yapmıştır. Nitekim Fransa da İngiltere gibi Yunanlıları desteklerken Amerika ise her iki devlete karşı da olumlu bir tutum sergilemiştir. İzmir'in Yunanistan'a verilmesi için oluşturulan uzman kurulu 8 Nisan 1919 yılında İzmir' in Yunanistan'a verilmesini kararlaştırmıştır. İtalyan temsilcisi, kendilerine haksızlık yapıldığ 1 gerekçesiyle 24 Nisan'da konferanstan çekilmiş ve bunun üzerine İzmir'in Yunanlılara verilmesi konusunda müttefik devletler hemfikir olmuştur. Akabinde ise Yunanistan'ın İzmir'i işgal etmesi için yasal zemin süreci hazırlanmaya başlanılmıştır. ${ }^{10}$

Orbay, Cehennem Değirmeni- Siyası Hatıralarım, Emre Yayınları, İstanbul, 1993, s.125. İngiltere adına Mondros Ateşkes Antlaşmasını imzalatan Amiral Calthorpe, Rauf Bey'e, İtilaf Devletlerinden herhangi birinin İstanbul ve boğazlar üzerinde bir askeri varlık göstermeyeceklerine dair söz vermiştir. Rauf Orbay, bu söze o kadar güvenmiş itimat etmiştir ki, İngiliz murahhassılarına hüsnü kabul gösterip, mütareke şartlarını gayet açık bir lisanla belirleyip, devletin ve saltanatın istikbalini kurtardıklarını beyan etmiştir. Fakat kısa sürede Orbay'ın dediği gibi olmadığı görülmüş ve İngilizler Musul'u işgal etmiştir. Yenigün, 2 Kasım 1918.

7 Öztürk, “Mondros Mütarekesi”, s.272-273.

8 Mehmet Kılıç, Cumhuriyet Yolunun Kilometre Taşları, Okan Üniversitesi Yayınları, İstanbul, 2007, s.79.

9 Osman Olcay, Sevres Andlaşmasina Doğru, Ankara Üniversitesi Basımevi, Ankara, 1981, s. XXXIIXXXIV; Cevdet Küçük, "Sevr Antlaşması", D.İ.A., Cilt 37, Diyanet Vakfı Yayınları, İstanbul, 2009, s.1-2. Müsâvât, 30 Nisan 1919; Küçük, "Sevr Antlaşması", s.3-4. 
Yunanistan'ın, 6 Mayıs 1919 tarihinde ilk kez İzmir'e asker sevkiyatına izin verilmiştir. 13 Mayıs 1919'da ise İtilaf Devletleri, İzmir'in 15 Mayıs 1919'da sabahın erken vakitlerinde Yunanlılar tarafından işgal edileceğini kararlaştırmışlardır. ${ }^{11}$ İngiltere Yüksek Komiseri Amiral Calthorpe, 14 Mayıs 1919 akşamı, İzmir'in 15 Mayıs 1919'da sabahın erken vakitlerinde işgal edileceği bilgisini, İzmir Valisi İzzet Bey’e bildirmiştir. Vali İzzet Bey’e bildirilen işgal haberinin aynısı ise İngiltere'nin İzmir Konsolosu olan James Morgan tarafından, İngiliz Yarbay Ian Smith aracılı̆̆ıyla İzmir' de görev yapan 17. Kolordu Komutanı Ali Nadir Paşa'ya da iletilmiştir. Bu işgalin Mondros Ateşkes Antlaşmasının 7. maddesine dayanılarak yapılacağı belirtilerek, işgalin hukuka uygun olduğu izlenimi verilmeye çalışıldığı görülmektedir. İtilaf Devletleri, şehirde işgal sırasında herhangi bir karışıklık çıkmaması için tedbir alınmasını ve o gün Türk askerlerinin kışlalarda tutulmasını istemiştir. ${ }^{12} 15$ Mayıs 1919 tarihinde sabah 08.40'ta Yunan savaş gemileri, İtilaf Devletlerinden İngiltere ve İtalyanların da yardımı ve Amerikan savaş gemilerinin de desteğiyle İzmir'e çıkarma yapmıştır. Kordon boyuna ilk olarak 12.000 kişilik Yunan birliği çıkmış ${ }^{13}$ ve İzmir metropoliti şehre ilk çıkan bu Yunan askerlerini takdis etmiş ve orada bulunan bir papaz ise onlara 'Türkleri öldürün' diye bağırmıştır. Yunan kuvvetleri, şehir içine doğru ilerlerken, takma adı Hasan Tahsin olan Osman Nevres Bey, orada Yunanlılara karşı ilk kurşunu sıkmış ve şehit edilmiştir. ${ }^{14}$ Yunan kuvvetleri, şehirde iki gün içinde beş bine yakın Türk'ü öldürerek şehit etmişlerdir. ${ }^{15}$

\section{2-İzmir'in İşgali Sonrası Tepkiler}

İşgal karşısında Osmanlı Hükümetinin ciddi bir adım atmadığı görülmektedir. Hatta Sadrazam Damat Ferit Paşa, Yunanlıların İzmir'i işgal etmesinin hemen akabinde hükümetinin istifasını padişaha sunmuştur. Ülke topraklarının işgal edildiği böyle bir zamanda kısa sürede olsa devlet hükümetsiz kalmıştır. Fakat Padişah istifayı kabul etmesine rağmen Damat Ferit Paşa'yı tekrar hükümeti kurması için görevlendirmiştir. Yeni hükümet işgalden ancak dört gün sonra 19 Mayıs 1919'da kurulmuştur. ${ }^{16}$ Sadrazam Damat Ferit Paşa, İzmir'i Yunanlıların işgal etmesini onaylamadıklarını fakat onların yerine gelebilecek herhangi bir devletin İzmir'de egemenliğini tanıyacaklarına dair, fütursuz açıklamalarda bulunmuştur. İçişleri Bakanı Ali Kemal ise Yunan işgalin geçici olduğunu belirtmiş ve özellikle o sırada Samsun'a çıkarak, Milli Mücadele hareketini başlatan Mustafa Kemal ve arkadaşlarını kastederek, onların Rumlardan daha tehlikeli olduğunu söylemiştir. ${ }^{17}$ Yunan işgali karşısında eli kolu bağlanan ve bir şey yapamayan İzmir Valisi İzzet Bey, işgalden sonra İzmir'de yaşanılan gelişmelere dair tafsilatlı bir rapor hazırlayarak, İstanbul Dahiliye Nezaretine göndermiştir. ${ }^{18}$ Bu rapor, İzmir'de Yunanlıların meydana getirdiği tahribatın ne kadar büyük olduğunu ve binlerce Türk’ün şehit edildiğini belgeleyen önemli bir kantttır.

11 Celal Bayar, Ben de Yazdım, Cilt VI, Baha Matbaas1, İstanbul, 1968, s.2004.

12 İsmail Ediz, Diploması ve Savaşs İngiliz Belgelerinde Batı Anadolu’da Yunan İşgali, Atatürk Araştırma Merkezi Yayınları, Ankara, 2015, s. 151.

13 İzmir'in işgali hakkında bilgi veren eserler için Bkz: Kâzım Özalp, Millî Mücadele 1919-1922, TTK. Yayınları, Ankara, 1972; Zekâi Güner, Millî Mücadele Başlarken Türk Kamuoyu, Kültür Bakanlı̆̆1 Yayınları, Ankara, 1999; Zeki Sarıhan, Kurtuluş Savaşı Günlüğü I, TTK. Yayınları, Ankara, 1993.

14 Kılıç, Cumhuriyet Yolunun Kilometre Taşları, s.104.

15 Doğanay-Açıkses, a.g.e., s. 66.

16 Sir Andrew Ryan, Sonuncu Dragoman, (Çev: Dilek Berilgen Cenkçiler), TTK., Ankara, 2015, s.128-130.

17 İstiklal Harbi Gazetesi, 17 Mayıs 1919.

18 Sabah, 22 Mayis 1919. 
İtilaf devletleri, kendilerinin destekleriyle Yunanistan'a işgal ettirdikleri İzmir'in, işgal haberini Türk ve dünya kamuoyuna duyurmamak için, orada bulunan bütün iletişim ve ulaşım hatlarına el koymuştur. Vatanlarının işgal edilmesi karşısında sessiz kalamayan İzmir Redd-i İlhak Cemiyeti Üyeleriyle İzmirli vatansever Türk telgrafçıları, gizlice telgraf çekerek İzmir'in işgal edildiği basına ve bütün yurda duyurmuşlardır. Telgrafta; Yunanlıların İtilaf Devletlerin yardımıyla şehirde Müslüman halkı katliama giriştikleri belirtilmiş ve İzmir'de kanın gövdeyi götürdüğünü vurgulamışlardır. Bütün herkesin Türk ordusuna yardım etmesi ve bu işgalin yurdun her tarafinda duyurulması istenilmiştir. ${ }^{19} \mathrm{Bu}$ telgraf halkta ve ulusal basında büyük bir yankı bulmuş ve telgraftan sonra İzmir'in Yunan kuvvetleri tarafindan işgal edilmesi, yurdun her tarafinda protestolarla karşılanmıştır. Akabinde ise bu konu özelinde yurt içinde birçok mitingler ve konuşmalar yapılarak, Anadolu'nun düşman işgalinden kurtarılması için manevi alt yapı oluşturulmaya çalışılmıştır.

İzmir'in işgalinden sonra düzenlenen mitinglerde Türk Ocakları'nın büyük faaliyetleri olmuştur. Türk Ocakları ve Karakol Cemiyeti mitinglerin koordine edilmesini sağlamış ve işgalin akabinden sonra, İstanbul'da düzenlenen protesto mitinglerinin yapılmasına öncülük etmişlerdir. Türk Ocakları haricinde İstanbul Darülfünun'unda ders veren hocalar ve orada eğitim gören öğrenciler gerek mitinglerin düzenlenmesi gerekse de mitingler sırasında konuşmalar yapılmasında yer almışlardır. 18 Mayıs 1919 tarihinde Darülfünun' da bir toplantı yapılmış ve toplantı sonucunda; Yunanlıların İzmir'de yapmış oldukları işgalinin tüm yurt içinde protesto edilmesi istenilmiş ve düşmana karşı yapılacak olan savaşta müderris ve muallimlerin başkan olarak halkın önünde yer alması gibi bazı kararlar alınmıştır. ${ }^{20}$

Mustafa Kemal Paşa, İzmir'in işgal edilmesinden dört gün sonra 19 Mayıs 1919'da Bandırma Vapuru ile Samsuna doğru çıkmıştır. 20 Mayıs 1919'da, Sadaret Makamına (Başbakanlık) bir telgraf çekmiş ve bu telgrafta Yunanlıların İzmir'i işgal etmeleri olayının hem milleti hem de orduyu tarif edilemeyecek şekilde sarstığını ve yaraladığını belirtmiş, millet ve ordunun el ele vererek, vatanlarına ve Türk varlığına karşı yapılan bu haksız tecavüze karşı direneceğini söylemiştir. ${ }^{21}$

İzmir'in işgal edilmesinden sonra İstanbul'da ilk miting, 19 Mayıs 1919 tarihinde Fatih'te yapılmış ve bu mitinge seksen bin kadar kişi katılmıştır. Miting sonucunda İzmir'in işgal edilmesinin herkes tarafindan protesto edilmesi kararlaştırılmış ve ayrıca padişaha da bir heyet gönderilerek milli değerleri benimseyen, vatan topraklarının işgali karşısında somut adımlar atabilecek bir kabine oluşturulması istenmiştir. ${ }^{22}$ Fatih mitingi sonucunda alınan kararlar, kendisinden sonra yapılmış olan mitinglere de emsal teşkil etmiş ve bu mitinglerin sonucunda da benzer kararlar alınmıştır.

Fatih mitinginden bir gün sonra ise İstanbul Üsküdar meydanında, 20 Mayıs 1919 tarihinde otuz bin kişinin katılımıyla bir miting tertip edilmiştir. Miting sonunda bir gün önce yapılan Fatih

19 Hakan Tartan, Atatürk' ün İzmir'i, TÜLOV Yayınları, İzmir, 2001, s.305. İzmir'in işgali sırasında şehirde yapılan soykırım, işkence, tecavüz, gasp için Bkz: Harp Tarihi Vesikaları Dergisi, Sayı 37, Vesika 907, Ankara, 1961; Askerî Tarih Belgeleri Dergisi, Belge No: 24/11-12-14, Ankara, 1992.

20 Vakit, 19 Mayıs 1919; İkdam, 9 Mayıs 1919; Volkan Marttin, "Türk Ocakları ve 100. Yılında Redd-i İlhak Beyannamesi”, Türk Yurdu, Y1l 108, Sayı 381, Mayıs 2019, s.85-91; Şevket Süreyya Aydemir, Tek Adam Mustafa Kemal (1919-1922), Remzi Kitabevi, İstanbul, 1999, s.82,83.

21 Atatürk ile Illgili Arşiv Belgeleri (1911-1921 Tarihleri Arasına Ait 106 Belge), T.C. Başbakanlık Osmanlı Arşiv Dairesi Yayını, Ankara, 1982, s.26.

22 Vakit, 20 Mayıs 1919; Tasvir-i Efkâr, 20 Mayıs 1919; İstiklal, 20 Mayıs 1919. 
mitinginde alınan kararlar aynen kabul edilmiş ve ayrıca da İzmir'in haksız yere işgal edildiği gerçeğinin bütün dünya basınına duyurulması kararlaştırılmıştır. ${ }^{23}$ İki gün sonra sonra ise 22 Mayıs 1919 tarihinde büyük bir kalabalıkla Kadıköy meydanında bir miting yapılmış, Fatih ve Üsküdar mitinglerinde konuşulan konular ve kabul edilen kararlar aynen kabul edilerek, pekiştirilmiştir. ${ }^{24}$

\section{3- Büyük Sultan Ahmet Mitingleri}

\subsection{Sultan Ahmet Meydanının Tarihi Önemi ve Konumu}

Sultan Ahmet Meydanı'nın, Roma İmparatoru olan Septimus Severus tarafindan M.S. 195196 tarihlerinde yaptırılmış ve yaptırılan bu kısım Hipodrum olarak kullanılmıştır. Severus'un ölümü ile tam bitmemiş olan meydan, İmparator Konstantin tarafindan, 324-337 tarihleri arasında daha da genişletilerek tamamlamıştır. ${ }^{25}$ Sultan Ahmet Meydanı, uzun asırlar boyunca İstanbul'da sosyal ve törensel etkinliklerin yapıldığı en önemli mekanlarından birisi olmuştur. Meydan olma özelliğini gerek Bizans döneminde gerekse de Osmanlı döneminde, tarih boyunca korumuştur. Sultan Ahmet Meydanı İstanbul'da Beyazıt Meydaniyla beraber, 'meydan' olarak tanımlanan yerlerden birisidir. $\mathrm{Bu}$ meydanda Bizans Döneminde at yarışları ve araba yarışlarının yanı sıra akrobasi gösterileri, danslar ve vahşi hayvan mücadeleleri de sergilenmiştir. Osmanlı Devleti, bu meydanda sadece at yarışları yaptırmamış bunun yanı sıra çeşitli törenler yapılmasına izin vermiş ve cirit oyunları da oynatmışıtır. Ayrıca bu meydan Yeniçeri ayaklanmalarına da ev sahipliği yapmış ve çıkarılan isyanlar da toplanma alanlarının merkezi olmuştur. Sultan Ahmet Meydanı, 18. yüzyılın sonlarına doğru önceki dönemlere göre olan merkezi önemini kaybetmiştir. Fakat Sultan Ahmet Meydanının gerek merkezi konumda olması gerekse yöneticilerin buraya ayrı bir ihtimam göstermeleri neticesinde tekrar XIX. yüzyılda eski önemi kazanmış ve ilgi odağı haline gelmiştir. ${ }^{26}$

Sultan Ahmet' e meydan özelliğini kazandırılmasında Bizans kadar Osmanlı Devletinin de pay sahibi olduğunu söylemek mümkündür. Çünkü Osmanlı Devleti daha önce boş denebilecek bu meydana, Sultan Ahmet Külliyesi'ni inşa etmiş, etrafını da bu minvalde düzenlemiş ve genişletmiştir. Hatta bundan dolayı olsa gerek ki Osmanlı Dönemi yazışmalarında "İstanbul şehrinin asıl kamusal alanı" olarak ifade edilirken; Külliye yapılmasından sonra ve günümüzde de Sultan Ahmet Meydanı olarak adlandırılmıştır. Bütün bunların yanında Sultan Ahmet Meydanı, Osmanlı Devletin de de birçok ilklere ev sahipliği yapmıştır. Meydan, Osmanlı da Batılı anlamda yapılan veya düzenlenen ilk park olmuştur. 1863'te de Osmanlı da ilk sergi binasına ev sahipliği yapmıştır. Sergi binası yapılırken meydanın etrafı da düzenlenmiş ve meydan kenarlarına kaldırımlar yapılmıştır. Düzenlenmiş olan bu parkın 1890 yılında da tekrar çevre düzenlemesi yapılarak daha geniş ve daha büyük bir bahçe haline getirilmesi planlanmış fakat daha sonra bahçe haline getirilmesinin uygun

23 İleri, 21 Mayıs 1919; Vakit, 21 Mayıs 1919.

24 İleri, 23 Mayıs 1919; Vakit, 23 Mayıs 1919.

25 Günümüzde Sultan Ahmet Meydanı, İstanbul'un en önemli turistik semti olarak kabul edilmektedir. Bu meydanda Sultan Ahmet Camisi ile birlikte Ayasofya Camii, İbrahim Paşa Sarayı ve Marmara Üniversitesinin Rektörlüğü vardır. Bkz:Aybike Yıldız, Tarihsel Birikime Sahip Kentsel Açık Alanların Dinamizmi - İstanbul Kent Örneği; Beyazıt Meydanı, Sultanahmet Meydanı Ve Taksim Meydanı, (Basılmamış Yüksek Lisans Tezi), İstanbul Üniversitesi Fen Bilimleri Enstitüsü, Aralık 2007, s.66-67.

26 Nurcan Yazıc1, “On dokuzuncu Yüzyılda Sultanahmet Meydanı”, İdealkent, Sayı 2, Aralık 2010, s.64,82; Nahit Yıldırım, Constatinopolis Hipodromu, (Basılmamış Yüksek Lisans Tezi), Selçuk Üniversitesi Sosyal Bilimler Enstitüsü, Konya-2013, s.1. 
olmadığı görüldüğü için vazgeçilmiştir. Meydana, Tanzimat döneminden itibaren yapılan kamusal alanlar II. Abdülhamit Döneminde hız kazanarak, sayıları bir hayli artırılmıştır. ${ }^{27}$ Sultan Ahmet Meydanı bütün bunların haricinde Osmanlı Devletinin son döneminde üç tane büyük mitinge de ev sahipliği yapmıştır.

\subsection{Birinci Sultan Ahmet Mitingi}

İzmir'in işgali karşısında düzenlenen Fatih, Üsküdar ve Kadıköy mitinglerden, sonra açık havada düzenlenen dördüncü miting, 23 Mayıs 1919 tarihinde Sultan Ahmet meydanında yapılmıştır. Sultan Ahmet meydanında bunun haricinde iki miting daha gerçekleştirilmiş ve 23 Mayıs 1919' da yapılan bu miting, Birinci Sultan Ahmet Mitingi adıyla tarihte yer almıştır. ${ }^{28}$ Mitingin düzenlenilmesinde Türk Ocaklarının yanı sıra Milli Kongrenin de önemli katkıları olmuştur. ${ }^{29}$

Mitingin yapılacağı günün bir hafta öncesinden, bütün İstanbul halkının mitingden haberdar olması ve mitinge davet etmek için çeşitli davetiyeler basılarak dağıtılmıştır. Bu davetiyelerin içeriği şu şekilde olmuştur: "Müslüman, Önümüzdeki Cuma günü resmi dua günüdür. Bugünde Fatih, Sultan Ahmet, Beyazıt camilerinde Cuma namazından sonra Müslüman ve Türk yurtlarının kurtuluşu için dua edilecektir. Camilerde, evlerde tazarru et, duadan sonra Allah'a yükselen kalbinle Sultan Ahmet'e bütün ve umumi içtima'a gel. Vatanın parçalanıyor. Öldürücü felaketler yağıyor. Camilerini mukaddesatını çiğneyecekler. Gözlerini aç, düşmanlarını, milletini düşün. İzmir facialarını öğren Anadolu senin de kararını bekliyor. Haksızlıklara karşı feryat et. Alemin vicdanına hitap eden heyecanlarla hakkını müdafaaya ve parçalanan vatanının imdadına koş. Bu mitingde kurtarıcı kararını ver ve kurtuluşun için çalışmaya yemin et. "'30 Bu davetiyelerde dinin ön plana çıkarılması ve halkın maneviyat altında birleştirilmesinin amaçlandığı görülmektedir. Bunun için bu davetiyelerde Cuma namazının kılınmasından sonra bütün herkesin işini gücünü bırakıp miting meydanlarına toplanması istenmiştir. ${ }^{31}$

Birinci Sultan Ahmet Mitingi, İzmir’in işgali karşısında düzenlenen mitingler arasında gerek insan kalabalığı olarak gerekse de ulusal ve yurtdışı basınında en çok ses getiren miting olmuştur. En çok katılım bu mitingde olmuş ve yüz binden fazla insanla, elliden fazla cemiyet, dernek ve parti bu mitinge katılmıştır. Mitinge katılan insanlar tarafından 'İzmir Türk'tür. Türk kalacaktır. Türk esir edilemez ve Rumlara feda edilemez. İki milyon Türk, iki yüz bin Rum'a feda edilemez" gibi sloganlar atılmış ve aynı zamanda bu sloganlar bez veya karton dövizlere de yazılarak, herkesin görüp okuyacağı bir biçimde meydan da dolaştırılmıştır. ${ }^{32}$

Sultan Ahmet meydanında toplanan büyük kalabalığa konuşma yapılabilmesi için meydana hakim konumda olan ve cami tarafında bulunan duvarın yanına, konuşmacıların hitap edebilmeleri

27 Yazıc1, a.g.m., s.65-67, 81.

28 İstiklâl Harbi Gazetesi, 24 Mayıs 1919.

29 Mithat Sertoğlu, “Tarihimizde İlk Milli Kongre”, Belgelerle Türk Tarihi Dergisi, Sayı 21, Haziran-1969, s.3-8

30 Zekai Güner-Orhan Kabataş, Millî Mücadele Dönemi Beyannameleri ve Basını ve Ankara, Atatürk Kültür Merkezi Yayınları, Ankara 1990, s. 78.

31 Enver Behnan Şapolyo, İstiklâl Savaşı Edebiyatı Tarihi Nesirler ve Şiirler (Milli Mücadelenin Edebi Vesikaları) 1919-1923, Ak Kitabevi, İstanbul, 1968, s.27.

32 İstiklâl Harbi Gazetesi, 24 Mayıs 1919. 
için bir kürsü yerleştirilmiştir. ${ }^{33}$ Bu kürsünün tam önüne denk gelebilecek bir şekilde siyah bir çerçeve içerisine de Wilson Prensiplerinin 12. maddesi yazılmıştır. ${ }^{34}$ Wilson Prensiplerinin bu maddesi yazılarak özellikle halkının tamamına yakını Türk olan Anadolu'nun ve bilhassa da İzmir'in Türklerin elinde kalabilmesi için bu yönde ilk söylemlerin oluşturulmaya çalışıldığı görülmektedir.

Bu mitingde; Muallimler Cemiyeti başkanı Selim Sırrı Bey, Halide Edip (Adıvar), Türk milliyetçiliğini ön plana çıkaran şair Mehmet Emin (Yurdakul), Dr. Sabit Bey ve bütün basın mensupları adına Fahrettin Hayri Bey konuşma yapmışlardır. ${ }^{35}$ Sultan Ahmet mitinginde ilk konuşmayı şair Mehmet Emin Yurdakul yapmıştır. Mehmet Emin "Kardeşlerim" hitabıyla konuşmaya başlamış, konuşmanın devamında vatanın düşman işgali altında bulunduğundan bahsederek, sözü İzmir'in Yunanlılar tarafinda işgal edilmesine getirmiştir. İzmir'in işgal edilmesini "kara günler" olarak nitelendirmiştir. Yurdakul, Yüce Allah, keşke bana bu kara günleri göstermeseydi diyerek olayın gerçek vahametini halka anlatmaya çalışmıştır. ${ }^{36}$ Yurdakul, altı asırdan beri İzmir'in camilerinde ezanlar okunduğunu ve bu minarelerden yayılan ezan seslerinin yeri göğü inlettiğini belirterek, İzmir'in Türk ve Müslüman yurdu olarak kalacağını söylemiştir. ${ }^{37}$ Yurdakul'un, bu mitingde yaptığı konuşma ve halkta uyandırdığı tesiri, mitinge hem konuşmacı hem de dinleyici olarak katılan Halide Edip Adıvar'ın, 1923 yılında yazdığı ve Türk edebiyatında Kurtuluş Savaşı üzerine yazılan ilk roman olan Ateşten Gömlek adlı eserinde anlatmıştır. Adıvar, burada Mehmet Emin Bey'i vatansever bir şair olarak nitelendirmiş ve onun konuşma yaptığı sırada beyaz olan başını milli bir aziz veya bir evliyaya benzetmiştir. ${ }^{38}$ Mehmet Emin Yurdakul'un bu mitingde ve daha sonra ki Milli Mücadele yıllarında yaptığ 1 konuşmalar, halk nezdinde hep olumlu karşılanmış ve büyük etkiler bırakmıştır. Hatta M. Fuat Köprülü, Türklerin yaralarını saranın sadece Mehmet Emin Yurdakul olduğunu söyleyerek, onu övmüştür. ${ }^{39}$

Mehmet Emin Yurdakul'dan sonra kürsüye, İstanbul'da Yunan işgalini tanımayan bütün basın mensupları adına Fahrettin Bey çıkmıştır. Fahrettin Bey, etkileyici bir konuşma yapmış ve akabinde de Tevfik Fikret'e ait olan; 'Zalimin topu var, güllesi var, kal'ası varsa- Halkın da bükülmez kolu, dönmez yüzü vardır' dizelerini söyleyerek kürsüden inmiştir. ${ }^{40}$

33 Hatiplerin konuşma yaptığı bu kürsünün mahiyeti hakkında Halide Edip Adıvar Ateşten Gömlek adlı romanında bilgi vermektedir. Kürsünün Sultan Ahmet Camisinin iki beyaz minaresinin önünde bulunan asırlık çınarların arasında siyah bayraklar altında konumlandırıldığını belirtmiştir. Kürsünün, küçük ve siyah renkte olduğuna değinerek, bütün seslerin onun çevresinden geldiğini söylemiştir. Halide Edip Adıvar, Ateşten Gömlek, Can Yay, İstanbul, 2009, s.43,44.

34 Mehmet Şahingöz, "Millî Mücadele'de Protesto ve Mitingler", Türkler, Cilt XV, Yeni Türkiye Yayınları, Ankara, 2002, s.728. Bu 12. Madde Osmanlı Devletinin topraklarına ve halklarına yöneliktir. Çünkü Türk topraklarının bulunduğu stratejik konum, ABD açısından çok önemliydi. Asena Boztaş, "Wilson İlkeleri’nin Türk Dış Politikasına Yansımaları: Realist ve Pragmatist Bir Perspektif”, Akademik Bakış, Cilt 7, Say1 14, Yaz 2014, s.169

35 Vakit, 24 Mayıs 1919,

36 Tayyip Gökbilgin, Milli Mücadele Başlarken, İş Bankası Kültür Yayınları, İstanbul, 2011, s.89.

37 Sarıhan, a.g.e, s.270-272.

38 Adıvar, Ateşten Gömlek, s.44

39 Fevziye Abdullah Tansel, "Mehmet Emin Yurdakul'un Eserleri-1 Şiirler”, Türk Sazı, TTK., Ankara, 1989, s.XLIII.

40 Sarıhan, a.g.e, s.270-272. 
Fahrettin Bey’in konuşmasından sonra kürsüye Halide Edip çıkmıştır. Halide Edip, daha önceki mitinglerde de konuşmalar yapmış fakat onun daha da tanınmasını ve ileride Milli Mücadele de en öne çıkan kadınlardan biri olmasını sağlayan konuşmasını Birinci Sultan Ahmet Mitinginde yapmıştır. Burada halkın milli ve dini duygularını harekete geçirici konuşmalar yaptığı için, tarihe ateşli konuşmalar yapan hatip olarak geçmiştir. Halide Edip, konuşmasına "Kardeşleri, evlatlarım" diyerek başlamış ve bir çok konuya değinmiştir. ${ }^{41}$ Halide Edip, konuşmasının sonunda bütün dinleyicilere; insanlık ve adalet prensiplerine bağlı kalacaklarına ve her ne zorluk olursa olsun hiçbir güç ve kuvvete boyun eğmeyeceklerine dair bir yemin ettirmiştir. ${ }^{42}$ İnci Enginün, Ziya Gökalp ile Yahya Kemal Beyatlı'nın, Halide Edip'in Sultan Ahmet Mitinginde yaptığı konuşmaya değindiklerini ve onu takdir ettiklerini belirtmiştir. Enginün, Halide Edip ismiyle Birinci Sultan Ahmet mitinginin, adeta birbiriyle özdeşleştiğini söylemiştir. ${ }^{43}$

Halide Edip, Ateşten Gömlek adlı romanında mitinge katılan insanları kastederek, asıl Türkiye'yi ben o zaman gördüm, demiştir. Hamal ile genç münevverin, Karagümrüklü işçi ile İstanbullu kadın ve yüksek ökçeli süslü kadının, omuz omuza yüz yüze geldiği gün olarak tasvir etmiştir. Halide Edip, Sultan Ahmet Meydanı'na atıf yaparak, daha önce burada ne imparatorlar ve imparatoriçelerin en görkemli alaylar, yarışlar, geçiş törenleri yaptıklarını belirtmiş; fakat bu meydanın bu gün olmadığı kadar hiçbir gün bütün bir milletin gözyaşıyla hiçbir görkemli alay, hiçbir Bizans ve Osmanlı ihtişamını kutlamadı̆̆ını söylemiştir. ${ }^{44}$

Birinci Sultan Ahmet mitinginin yurt sathındaki ulusal gazetelerde de geniş yer aldığ1 görülmektedir. Alemdar gazetesi, vatanın tehlikede olduğunu ve vatanı kurtaracak olan tek kuvvetin milli birlik ve beraberlikle hareket edilmekle olacağını belirterek, bütün İstanbul halkının muazzam ve büyük bir mitinge hazırlandığını söylemiştir. Alemdar, bütün İstanbul esnafinın dükkanlarını kapatıp, Sultanahmet Camisine koştuğunu yazmıştır. ${ }^{45}$ Hadisat gazetesi ise, böyle muazzam büyüklükte bir mitingin tarihin hiçbir safhasında daha önce hiç görülmediğini, Müslüman ve Türk olan bütün İstanbul halkının akın akın Sultan Ahmet meydanına toplanarak, haklarını aradıklarını ve yurtlarını kimseye vermeyeceklerini haykırdıklarını belirtmiştir. ${ }^{46} \mathrm{Bu}$ miting, sadece Sultan Ahmet meydanını dolduran halkta değil yurdun bütün her yerinde büyük ses getirmiştir. Nitekim Ali Fuat Cebesoy'da hatıralarında, Sultan Ahmet mitingin de konuşulan her şeyin ve miting sonunda alınan kararların bütün Anadolu’ya kısa sürede yayıldığını ve ileride başlayacak olan Milli Mücadele Dönemi için büyük destek sağladığını belirtmiştir. ${ }^{47} \mathrm{Bu}$ mitingin bütün Anadolu da yayılıp ses getirmesi, halkı bilinçlendirerek, vatanlarını işgal eden düşmana karşı harekete geçmelerini hızlandırması durumu başta İngiltere olmak üzere bütün İtilaf devletlerini endişeye sevk etmiştir. ${ }^{48}$ Kitapevi, İstanbul, 1987, s.34-35. Adıvar, Ateşten Gömlek, s.43,44. Alemdâr, 23 Mayıs 1335.

Hadisat, 24 Mayıs 1335.
Enver Behnan Şapolyo, İstiklal Savaşı Edebiyatı Tarihi, Ak Kitapevi, İstanbul, 1967, s.30-32. İnci Enginün, Halide Edib Adıvar, Kültür Bakanlığı Yayınları, Ankara, 1989, s.16.

Ali Fuat Cebesoy, Millî Mücadele Hatıralarl, Vatan Neşriyat, İstanbul,1953, s.63. Refik Halit Karay, Minelbab İlelmihrab, İnkılâp ve Aka Kitapevleri, İstanbul,1964, s.125. 


\section{3. İkinci Sultan Ahmet Mitingi}

30 Mayıs 1919 tarihinde, Birinci Sultanahmet mitinginden bir hafta sonra, Cuma günü İkinci Sultan Ahmet mitingi yapılmış ve yüz binden fazla kişi bu mitinge katılmıştır. ${ }^{49}$ Halk Birinci Sultan Ahmet Mitinginde attığı sloganların aynısını burada da atmış ve "Osmanlı topră̆g Yunanistan olamaz. İki milyon Türk iki yüz Rum'a feda edilemez" yazılı dövizleri meydanda taşımışlardır. ${ }^{50}$

İkinci Sultan Ahmet Mitinginde konuşma yapan hatiplerin, bir hafta önce yapılan mitingdeki kişilerden farklı oldukları görülmektedir. Bu mitingde İstanbul Darülfünun'u daha ön plana çımış ve Darülfünun hocalarından İsmail Hakkı (Baltacıoğlu), o sırada yeni mezun olmuş Darülfünun öğrencisi Şükûfe Nihal konuşma yapmışlardır. Dr. İsmail Hakkı (Milaslı) Bey ve Hamdullah Suphi (Tanrı̈̈ver) de konuşmalar yapmışlardır. Miting, Birinci Sultan Ahmet Mitinginde olduğu gibi Cuma günü Cuma namazı kılındıktan sonra başlamıştır. Sultan Ahmet Camisinde vatanın kurtuluşu ve birlik-beraberlik temalı dualar edildikten sonra, kürsüye ilk olarak müderris İsmail Hakkı Bey çıkmıştır. İsmail Hakkı; düşmana karşı daima ses çıkartarak haklı oldukları gerçeğini İtilaf Devletlerine duyurmaları gerektiğini, Avrupalıların Türkleri yok etmek istediklerini, eğer Avrupalılar Anadolu'da işgale devam ederlerse her zaman onlarla mücadele yapmak için hazır olduklarını söylemiştir. ${ }^{51}$ İsmail Hakkı'nın yaptığı konuşmada İtilaf Devletlerine vurgu yaptığı görülmektedir. Bu vurgu önemlidir. Çünkü Anadolu'da gözü olan ve İzmir'i işgal eden Yunanlılara destek verenler İtilaf Devletleridir.

İsmail Hakkı'dan sonra kürsüye Şükûfe Nihal çıkmış ve halkı etkileyecek derecede hitap etmiştir. Birinci Sultan Ahmet Mitingine Halide Edip nasıl damgasını vurmuş ve "ateşli konuşmalar yapan hatip" kadın olarak nitelendirildiyse, bu mitinge de Şükûfe Nihal'in damgasını vurduğunu söylemek mümkündür. Şükûfe Nihal, konuşmasında kullandığı sözlerini özenle seçmiş ve bunları edebi ve lirik cümlelerle destekleyerek, milli birlik ve beraberliği, vatan sevgisini ön plana çıkaran bir konuşma yapmıştır. Konuşmaya damgasını vuran ve tarihe geçen "Aziz vatan, beşiğimiz sendin, mezarımız yine sen olacaksın!" cümlesini söyleyerek konuşmasını bitirmiştir. ${ }^{52}$

Şükûfe Nihal'in konuşmasının ardından Dr. İsmail Hakkı (Milaslı) Bey kürsüye çıkmış ve medeniyet sahibi olan ve büyük fikir adamları yetiştiren Avrupalıların, Türk topraklarında yapılan bu işgale ve zulme engel olmaları gerektiğini belirtmiştir. Wilson Prensiplerinin 12. maddesinde yer alan ve nüfusun çoğunluğunu Türklerin oluşturduğu yerlerin idaresinin Türklere bırakılacağ sözünün bir an önce uygulanması gerektiğini dile getirmiştir. ${ }^{53}$ İsmail Hakkı, Yunanlıların ve İtilaf Devletlerinin yaptıklarını vahşilik ve onları ise vahşiler olarak nitelendirmiştir. Konuşmasında, Yunanlıların ve İtilaf Devletlerinin İzmir'de büyük bir zulüm yaptıklarını ve bu zulüm karşısında Avrupalıların sessiz kaldığını belirterek, Avrupalı devletlere güvenilmeyeceğini ifade etmiştir. ${ }^{54}$

\footnotetext{
49 Alemdâr, 31 Mayıs 1335; Şahingöz, a.g.m., s.728.

50 Hadisat, 31 Mayıs 1335.

51 Hadisat, 31 Mayıs 1335; Arıburnu, a.g.e., s.51-53.

52 Vakit, 31.05.1919; İleri, 31.05.1919; Hülya Argunşah, Bir Cumhuriyet Kadını: Şukufe Nihal, Akçağ Yayınlar1, Ankara, 2003, s. 15-40.

53 Arıburnu, a.g.e., s.56.

54 Resul Çatalbaş, “Milaslı Dr. İsmail Hakkı'nın Hayatı, Eserleri ve İslam İle İlgili Görüşleri”, Artuklu Akademi, 2014/1 (1), s.101.
} 
Bu mitingde konuşmacilar tarafından genel olarak Wilson Prensiplerinin 12. maddesinin bir an önce uygulanması gerektiği vurgulanılmış ve asırlardan beri Türk yurdu olan bu coğrafyanın Türklerin ellerinden alınamayacağı belirtilmiştir. Miting sonunda kabul edilen kararlar ve vatan topraklarının elinde tutulması için atılması istenilen adımlar, öncelikle Padişah ve hükümete bildirilmiş, daha sonra da aynı kararlar İtilaf devletlerinin temsilciliklerine de gönderilmiştir. ${ }^{55}$ İkinci Sultan Ahmet Mitingi de aynen Birinci Sultan Ahmet Mitingi gibi büyük bir etki ortaya çıkarmış ve gerek İstanbul'da ki gerekse de Anadolu'da ki insanları vatan sevgisi altında birleştirmiştir. İtilaf devletleri miting sonucunda halkın bilinçlendiğini görmüş ve İngiliz Yüksek Komiseri Calthorpe 31 Mayıs 1919 tarihinde Sadrazama, bundan sonra kesinlikle İstanbul ve çevresinde herhangi miting, protesto ve gösteri yapılmasına izin vermeyeceklerini bildirerek, hükümetin bu konuda gerekli önlemleri almasını istemiştir. Hükümet, bir genelge yayınlayarak, yurt içindeki yapılan işgallerin bir an önce önlemeleri için İtilaf devletleri ile görüştüklerini belirterek; İstanbul halkından herhangi bir olaya mahal verilmesinin önüne geçmek için sükunetli davranmaları gerektiği istenilmiştir. Bu genelgeden sonra 6 ay süre zarfında İstanbul'da herhangi bir miting yapılmadığı görülmektedir. ${ }^{56}$

\section{4. Üçüncü Sultan Ahmet Mitingi}

İtilaf Devletleri, Osmanlı'ya baskı yaparak İkinci Sultan Ahmet mitinginden sonra İstanbul'da herhangi bir mitingin yapılmasını yasaklatmıştır. Türk halkı dünya kamuoyuna seslerini duyurabilmek için Türk yurdunun haksız yere işgal edildiğine dair İtilaf Devletleri temsilcilerine telgraflar çekilmiş ve aydınlar tarafından gazetelerde birçok yazılar kaleme alınmıştır. 5 Ocak 1920'de Darülfünun öğrencileri bir toplantı yaparak, 13 Ocak 1920 tarihinde Sultan Ahmet meydanında bir miting yapılmasını planlamışlardır. ${ }^{57}$

Üçüncü Sultan Ahmet Mitingi, toplanış amaçları açısından Birinci ve İkinci Sultan Ahmet mitinglerinden farklı olduğu görülmektedir. Çünkü ilk iki mitingde İzmir'in işgaline tepki ve protesto biçiminde gerçekleştirilmişken, bu mitingde tamamen farklı amaçlar gözetilmiştir. Mondros Ateşkes Antlaşmasından 1920'li yılların başına kadar olmuş olan mitingler işgallere tepki verme amacıyla yapılmışken Üçüncü Sultan Ahmet Mitingi, İtilaf Devletlerin gelecekte Osmanlı Devletinin ve halkının kaderini-belirleyen kararlar alma amacında oldukları bir dönemde, onlara tepki göstermek amacıyla yapılmıştır. Çünkü bu sırada İngiliz Dışişleri Bakanı Lord Curzon, 4 Ocak 1920'de İngiliz kabinesine, Türklerin bir an önce İstanbul ve Avrupa'dan çıkarılarak atılması gerektiğini belirtmiştir. İngiliz Muhipleri Cemiyetine mensup olan Osmanlı üyeleri Lord Curzon'a mektup yazmışlar ve bu mektupta Doğu Trakya ile İstanbul'un Türklerin elinden alınacağı söylentilerinden kaygı ve endişe duyduklarını dile getirmişlerdir. ${ }^{58}$

Miting, planlanan tarihte olmuş ve 13 Ocak 1920 tarihinde Sultan Ahmet mitinglerinden en sonu olan üçüncü miting yapılmıştır. ${ }^{59}$ Ayrıca, Üçüncü Sultan Ahmet Mitingi, Milli Mücadele Döneminde İstanbul'da yapılan son büyük miting olmuştur. ${ }^{60} \mathrm{Bu}$ mitinge yüz elli binden fazla

55 Şahingöz, a.g.m., s.728-729; Arıburnu, a.g.e., s.58-60.

56 Gotthard Jaeschke, Türk Kurtuluş Savaşı Kronolojisi, TTK Basımevi, Ankara, 1989, s.39.

57 Tasvir-i Efkar, 6 Ocak 1920.

58 Volkan Marttin, “Misak-1 Millî’nin Kabulü Ve İstanbul'un İşgali Sürecinde 1920 Sultanahmet Protesto Mitingi’nin Önemi Ve Etkisi”, Çağdaş Türkiye Tarihi Araştırmaları Dergisi, XVIII/Özel Sayı (2018), s.266-268.

59 Vakit, 13,14 Ocak 1920; İfham, 14 Ocak 1920.

60 Sina Akşin, İstanbul Hükümetleri ve Millî Mücadele, Cilt II: Son Meşrutiyet (1919-1920), Türkiye İş 
insan katılmıştır. Mitingde, Rıza Tevfik Bey, Hamdullah Suphi (Tanrı̈ver) Bey ve Muallimler Cemiyeti Başkanı Nakiye (Elgün) Hanım konuşmalar yapmıştır. ${ }^{61}$ Diğer mitinglerde olduğu gibi Cuma namazının akabinde yapılan dualardan sonra tekbir sesleriyle kürsüye ilk olarak Riza Nur Bey çıkmış ve vatanın işgal altında olduğunu, büyük bir felaket ile karşı karşıya olduklarını belirterek konuşmasını başlatmıştır.

Rıza Tevfik, Türklerin de Avrupalılar gibi medeni bir millet olduğuna değinmiş ve Türklerin medeni bir millet olduklarına dair tarihten örnekler vermiş̧ir. Fakat Avrupalıların Türkleri medeni insanlar gibi görmek istemediklerini belirtere ${ }^{62}$ Türklere medeniyetsizdir iftirası atanın yalancı olduğunu söylemiştir. Riza Tevfik; İslâm döneminde Bağdat'ta kurulan medeniyette en büyük payın Türklere ait olduğunu, hatta en büyük Arapça sözlük yazan kişinin bir Türk olduğunu söyleyerek eliyle Sultan Ahmet Camisini göstermiş, bu mübarek camiyi Türklerin yaptı̆̆ını ve bunun gibi eserlerin hep Türk varlığının ve Türk medeniyetinin yüksekliğine delalet ettiğini vurgulamıştır. ${ }^{63}$

Riza Tevfik Bey'den sonra 1914-1917 yılları arasından Sultan Ahmet Vakfinın hem müdireliğini yapan ${ }^{64}$ ve hem de öğretmen olarak görev alan Nakiye (Elgün) Hanım söz almıştır. Ayrıca o sırada Muallimler Cemiyeti'nin de başkanlığını yürütmektedir. ${ }^{65}$ Nakiye Hanım, bir kadın olarak hitap ettiğini belirterek söze başlamış ve içinizde atalarının mezarlarını, onların yaptırmış oldukları cami ve türbeleri bırakacak bir erkek var mı diye sormuştur. Böyle bir durumu asla tasavvur bile etmediğini ve kadınlar olarak erkeklerle beraber olup, onların yanından ayrılmayarak, vatan topraklarını düşmanlara karşı hep birlikte müdafaa edeceklerini söylemiştir. Vatanın kurtuluşunda erkekler kadar kadınlarında yer alacağını belirtmiş, bu yolda gerekirse ölebileceklerini ifade etmiştir. Nakiye Hanım, konuşmasında son söz olarak önlerinde iki seçenek olduğunu belirtmiş, ya tekrardan Türklerin şanlı tarihlerine bağımsız olarak devam etmesi ya da Türk tarihini ebediyete kadar kapatması olarak ifade etmiş ve kürsüden inmiştir. ${ }^{66}$

Nakiye Hanımdan sonra kürsüye Hamdullah Suphi Bey çıkmış; Anadolu'nun geleceği hakkında başka devletlerin söz söylediğini ancak bu devletlerin buna hakkı olmadığını, millet olarak hak sahibinin Türkler olduğunu belirtmiş ve son söz söyleme hakkının Türklere ait olduğunu söylemiştir. Hamdullah Suphi, Anadolu'nun ve Trakya'nın da birbirinden koparılamayacağına değinerek, yurdun düşman tarafindan işgal edilmesine asla izin vermeyeceklerini ve bu konuda halk olarak ellerinden geleni yapacaklarını da belirtmiştir. ${ }^{67}$

Bankası Yayınları, Ankara, 1998, s.270.

61 Ariburnu, a.g.e., s.65-67.

62 Akşin, a.g.e., s.270.

63 Arıburnu, a.g.e., s.61-65.

64 Güldane Çolak, Lale Uçan, II. Meşrutiyet'ten Cumhuriyet'e Basında Kadın Öncüler, Heyamola Yayınları, İstanbul, 2008, s.92.

65 Leyla Kaplan, Cemiyetlerde ve Siyasi Teşkilatlarda Türk Kadını (1908-1960), Atatürk Araştırma Merkezi Yayınları, Ankara, 1998, s.75-80.

66 Arıburnu, a.g.e., s.65-70.

67 İleri, 14 Ocak 1920; Arıburnu, a.g.e., s.68-70; Hamdullah Suphi Bey daha sonra kendi kaleme aldığı ve Fethi Tevetoğlu tarafından hazırlanan eserinde Üçüncü Sultan Ahmet Mitingine ve burada verdiği nutka detaylı olarak değinmiştir. Hamdullah Subhî Tanrı̈ver, Dağ Yolu, Cilt I, (Hazırlayan: Fethi Tevetoğlu ), Kültür Bakanlığı Yayınları, Ankara, 2000, s.173. 
Hamdullah Suphi'nin, Fransa hakkında ki söylediği sözlerden dolayı olsa gerek, onun konuşmasından sonra Posta, Telgraf ve Telefon Genel Müdürü Yusuf Razi Bey'in Fransız etnik menşeli eşi Madam Jeannina kürsüye çıkmış ${ }^{68}$ ve kendisini dinleyen halka "Türkler ölmeyecektir" diye haykırmıştır. Madam Jeannina, konuşmasını bazen Fransızca ve bazen de Türkçe olarak sürdürmüş ve sözlerinin daha iyi anlaşılması için Hamdullah Suphi Bey’den, tercüme etmesini istemiştir. Madam Jeannina, Türkleri daha yakından tanıyan Fransızların, Türkleri sevdiğini belirtmiş ve bu haklı davalarında Fransızların Türkleri destekleyeceklerini vurgulamıştır. ${ }^{69}$ Burada Madam Jeannina'nın konuşmasında, Türkleri haklı olan bu mücadelede desteklerken bir çok önemli noktaya değindiğini görmekteyiz. Aynı zamanda Madam Jeannina'nın bu konuşmasının çok politik olduğunu söylemek mümkündür. Kendisi Fransız menşeli olan bu kadın, 1rkı olan Fransızların da Türkleri sevdiğini ve onları destekleyeceğini iddia etmiştir. Halbuki Fransızların Anadolu'da yaptığ 1 işgallere ve bıraktıkları tahribata bakıldığı zaman hiç de Madam Jeannina'nın iddia ettiği gibi olmadığı görülmektedir. Fransızlar, Mondros Ateşkes Antlaşması'nın imzalanmasının hemen akabinde Çukurova' da işgallere başlamış ve bu işgalleri 10 Nisan 1920 yılına kadar devam etmiştir.

Diğer mitinglerde olduğu gibi bu miting sonucunda da bazı kararlar alınmıştır. Alınan kararlar şunlardır: İstanbul'un başkent olarak kalması, Edirne'nin Türklere bırakılması ve Batı Anadolu'nun bütünü dahil olmak üzere İzmir' in Yunan ve diğer devletlerin işgalinden kurtarılmas1. ${ }^{70}$ Miting sonunda, miting düzenleme heyeti Yıldız sarayına giderek alınan bu kararları, padişah Vahdettin'e arz etmişlerdir. Heyet, kararlardan birer nüsha Sadrazam, Meclisi Mebusan ve Meclisi Ayan'a da vermiştir. Ayrıca alınan bu kararlardan İtilaf devletlerinin de haberdar olması için onların temsilcileri de ziyaret edilerek, bu durum bildirilmiştir. ${ }^{71}$ Veliaht Abdülmecit Efendi de Sultan Ahmet mitingini otomobilinin içinden takip etmiştir. Miting sonunda kendisini park kapısında alkışlayan talebelere teşekkür ederek, asla ümitsiz olmamaları gerektiğini belirtmiş ve mektepte okuyan gençlerden çok ümitli olduğunu söylemiştir. ${ }^{72}$

Üçüncü Sultan Ahmet Mitinginin, İngiliz gizli raporlarına yansıdığı da görülmektedir. İngiliz askeri istihbaratı 7-14 Ocak 1920 tarihli haftalık raporunda, İstanbul'da Sultan Ahmet'te büyük katılımlı bir miting yapıldığını belirtmiş ve mitingde ki konuşmacıların Amerikalıların Türklerin haklarını koruyacaklarını umduklarını söyledikleri vurgulanmıştır. ${ }^{73}$ Üçüncü Sultan Ahmet mitinginden sonra İngiltere'nin Yüksek Komiserliğine de bir protesto mektubu verilmiştir. Bu mektup, 3 Şubat 1920 tarihinde Amiral De Robeck tarafından Lord Curzon'a iletilmiştir. Mektupta, İstanbul şehrinin İtilaf kuvvetleri tarafından işgal edilmek istenmesi, şehrin ve özellikle de boğazların yönetiminin, uluslar arası bir komisyon tarafından kontrol edilmesinin düşünülmesi kınanmıştır. Hatta mektupta tehditkarvari bir tutum da sergilenmiş ve İstanbul işgal edilirse, bunun sonucunda ortaya çıkabilecek bütün hadiselerden özellikle İngilizlerin sorumlu tutulacağ1

68 Hanri Benazus, Bir Milletin Yeniden Doğuşu Türk Kadınının Uyanışı, Toplumsal Dönüşüm Yay., İstanbul, 2005, s.148,149.

69 Arıburnu, a.g.e., s.70-72.

70 İleri, 14 Ocak 1920; Arıburnu, a.g.e., s.68-70.

71 Vakit, 14 Ocak 1920.

72 İstiklal Harbi Gazetesi, 14 Ocak 1920.

73 Bilâl Şimşir, İngiliz Belgelerinde Atatürk (1919-1938), Cilt I (Nisan 1919-Mart 1920), TTK., Ankara, 1973, s.324. 


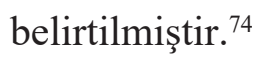

\section{Sonuç}

20. yüzyılın ilk başlarında Osmanlı Devleti hem toprakları içerisinde hem de toprakları dışında bir takım büyük sorunlarla karşılaşmış ve bütün bunlar Osmanlı Devletini yıkılma sürecine götürmüştür. Osmanlı devleti 1914-1918 yılları arasında vuku bulan I. Dünya Savaşında yenilmiş ve Mondros Ateşkes Antlaşmasını imzalayarak savaştan çekilmiştir. Ateşkes antlaşmasının imzalanmasının akabinde, Osmanlı Devletinin toprakları işgal edilmeye başlanmıştır. Anadolu'da yaşayan Türk milleti, yapılan bu işgallere tepki göstermiş ve bulundukları bölgede teşkilatlanarak topraklarını işgalci kuvvetlere karşı korumaya çalışmıştır. Özellikle İzmir'in 15 Mayıs 1919'da İtilaf Devletlerinin desteğini alan Yunanlılar tarafindan işgal edilmesi Anadolu'da ve İstanbul'da birçok tepkilere neden olmuştur.

Anadolu'da yaşayan halk sadece düşmana karşı savaşmakla kalmamış ve İzmir'in işgal edilmesi karşısında İstanbul'da birçok miting düzenlemişlerdir. Bu mitinglerin içerisinde en büyük olanı ve aynı zamanda da en çok etki bırakan miting ise Sultan Ahmet Mitingleri olmuştur. Sultan Ahmet mitingleri toplam da üç tane gerçekleştirilmiş ve ilk iki mitingde İzmir'in işgal edilmesine karşı düzenlenmişken, üçüncü Sultan Ahmet Mitinginin ise bunlardan farklı olarak İstanbul'un işgal edileceği söylentilerine karşı düzenlendiği görülmüştür. Sultan Ahmet mitinglerinde konuşma yapan hatiplerin farklı olduğu görülmektedir. Bu hatipler dönemin tanınan kişileri olmuş, vatan, millet ve bayrak temalı konuşmalar yaparak halkın milli duyguları harekete geçirmişlerdir. Etkileyici konuşmalar yaparak, halkı bilinçlendirmişler ve onları vatan topraklarını düşmana karşı savunmaları gerektiğine inandırmışlardır. Bu mitinglerde İslam dininin birleştirici gücü de kullanılmıştır. Mitingler, İslam dininin kutsal saydığı Cuma gününde, Cuma namazı kılındıktan sonra yapılmıştır. Mitinglerin, Cuma namazında edilen dualardan sonra yapılmasının halkın maneviyatı üzerinde kalıcı etkiler bıraktığı görülmüştür. Ayriyeten bu mitinglerde, Halide Edip, Şukufe Nihal, Nakiye Ergün gibi kadın konuşmacılar da söz almış, etkileyici konuşmalar yaparak, Türk milletini cesaretlendirmişlerdir.

Son söz olarak üç kere yapılan Sultan Ahmet Mitingleri, halk üzerinde büyük bir tesir meydana getirdiği görülmüştür. Sultan Ahmet Mitinglerine halk büyük destek vermiş ve 150-200 bin aralığında insan katılmıştır. Bu mitingler sadece yerel olarak kalmamış ve Türk topraklarında yapılan bu haksız işgallerin dünya kamuoyuna duyurulmasında da çok etkili olmuşlardır. Toplamda üç kere yapılan Sultan Ahmet Mitinglerinin üçüncüsü, İstanbul'da Milli Mücadele öncesi yapılan son büyük miting olmuş; gerek burada gerekse bundan önceki mitinglerde konuşulan konuların Milli Mücadele'ye çok büyük katkısı olmuş ve Milli Mücadele'nin zaferle kazanılmasını sağlamışlardır. 


\section{Kaynakça}

\section{Gazeteler}

Alemdâr, 23 Mayıs 1335.

Alemdâr, 31 Mayıs 1335

Hadisat, 24 Mayıs 1335

Hadisat, 31 Mayıs 1335

Hadisat, 31 Mayıs 1335.

İfham, 14 Ocak 1920.

İkdam, 9 Mayıs 1919.

İleri, 14 Ocak 1920.

İleri, 14 Ocak 1920.

İleri, 21 May1s 1919.

İleri, 23 Mayıs 1919.

İleri, 31.05.1919.

İstiklal Harbi Gazetesi, 24 Mayıs 1919.

İstiklal Harbi Gazetesi, 14 Ocak 1920.

İstiklal Harbi Gazetesi, 17 Mayıs 1919.

İstiklâl Harbi Gazetesi, 24 Mayıs 1919.

Müsâvât, 30 Nisan 1919

Sabah, 22 Mayıs 1919.

Tanin, 30 Eylül 1918.

Tasvir-i Efkâr, 20 Mayıs 1919;

Tasvir-i Efkar, 6 Ocak 1920.

Vakit, 13 Ocak 1920;

Vakit, 14 Ocak 1920.

Vakit, 19 Mayıs 1919

Vakit, 20 Mayıs 1919;

Vakit, 23 Mayıs 1919.

Vakit, 24 Mayıs 1919,

Vakit, 31 Mayıs 1919;

Vakit, 6,7,8 Ekim 1918. 
Vakit, 21 Mayıs 1919

Yenigün, 2 Kasım 1918.

\section{Telif Eserler}

Adıvar, Halide Edip, Ateşten Gömlek, Can Yay, İstanbul, 2009.

Adıvar, Halide Edip, Türk’ün Ateşle İmtihanı, Atlas Kitapevi, İstanbul, 1987.

Akşin, Sina, İstanbul Hükümetleri ve Millî Mücadele, Cilt II: Son Meşrutiyet (1919-1920), Türkiye İş Bankası Yayınları, Ankara, 1998.

Argunşah, Hülya, Bir Cumhuriyet Kadını: Şukufe Nihal, Akçağ Yayınları, Ankara, 2003.

Askerî Tarih Belgeleri Dergisi, Belge No: 24/11-12-14, Ankara, 1992.

Atatürk ile Illgili Arşiv Belgeleri (1911-1921 Tarihleri Arasına Ait 106 Belge), T.C. Başbakanlık Osmanlı Arşiv Dairesi Yayını, Ankara, 1982.

Aydemir, Şevket Süreyya, Tek Adam Mustafa Kemal (1919-1922), Remzi Kitabevi, İstanbul, 1999.

Bayar, Celal, Ben de Yazdım, Cilt VI, Baha Matbaası, İstanbul, 1968.

Benazus, Hanri, Bir Milletin Yeniden Doğuşu Türk Kadınının Uyanışı, Toplumsal Dönüşüm Yay., İstanbul, 2005.

Boztaş, Asena, “Wilson İlkeleri'nin Türk Dış Politikasına Yansımaları: Realist ve Pragmatist Bir Perspektif”, Akademik Bakış, Cilt 7, Sayı 14, Yaz 2014.

Cebesoy, Ali Fuat, Millî Mücadele Hatıraları, Vatan Neşriyat, İstanbul,1953.

Criss, Bilge, İşgal Altında İstanbul, İletişim Yayınları (2. Baskı), İstanbul, 1994.

Çatalbaş, Resul, “Milaslı Dr. İsmail Hakkı'nın Hayatı, Eserleri ve İslam İle İlgili Görüşleri”, Artuklu Akademi, 2014/1 (1).

Çolak, Güldane - Uçan, Lale, II. Meşrutiyet'ten Cumhuriyet'e Basında Kadın Öncüler, Heyamola Yayınları, İstanbul, 2008.

Doğanay, Rahmi - Açıkses, Erdal, Türkiye Cumhuriyeti Tarihi ve Atatürk İlkeleri, Manas Yayınları, Elazı̆̆ 2006.

Ediz, İsmail, Diploması ve Savaş İniliz Belgelerinde Batı Anadolu’da Yunan İşgali, Atatürk Araştırma Merkezi Yayınları, Ankara, 2015.

Enginün, İnci, Halide Edib Adıvar, Kültür Bakanlığı Yayınları, Ankara, 1989.

Gökbilgin, Tayyip, Milli Mücadele Başlarken, İş Bankası Kültür Yayınları, İstanbul, 2011.

Güner Zekai- Kabataş, Orhan, Millî Mücadele Dönemi Beyannameleri ve Basını ve Ankara, Atatürk Kültür Merkezi Yayınları, Ankara 1990.

Güner, Zekâi, Millî Mücadele Başlarken Türk Kamuoyu, Kültür Bakanlığı Yayınları, Ankara, 1999. 
Harp Tarihi Vesikaları Dergisi, Sayı 37, Vesika 907, Ankara, 1961.

Jaeschke, Gotthard, Türk Kurtuluş Savaşı Kronolojisi, TTK Basımevi, Ankara, 1989.

Kaplan, Leyla, Cemiyetlerde ve Siyasi Teşkilatlarda Türk Kadını (1908-1960), Atatürk Araştırma Merkezi Yayınları, Ankara, 1998.

Karay, Refik Halit, Minelbab İlelmihrab, İnk1lâp ve Aka Kitapevleri, İstanbul,1964.

Kılıç, Mehmet, Cumhuriyet Yolunun Kilometre Taşları, Okan Üniversitesi Yayınları, İstanbul, 2007.

Küçük, Cevdet, “Sevr Antlaşması”, DİA., Cilt 37, İstanbul, 2009.

Marttin, Volkan, “Misak-1 Millî’nin Kabulü Ve İstanbul'un İşgali Sürecinde 1920 Sultanahmet Protesto Mitingi'nin Önemi Ve Etkisi”, Çağdaş Türkiye Tarihi Araştırmaları Dergisi, XVIII/ Özel Sayı (2018).

Volkan Marttin, “Türk Ocakları ve 100. Y1lında Redd-i İlhak Beyannamesi”, Türk Yurdu, Y1l 108, Say1 381, Mayıs 2019.

Mühlman, Carl, İmparatorluğun Sonu 1914, Timaş Yayınları, İstanbul, 2014.

Olcay, Osman, Sevres Andlaşmasına Doğru, Ankara Üniversitesi Basımevi, Ankara, 1981.

Orbay, Rauf, Cehennem Değirmeni- Siyası Hatıralarım, Emre Yayınları, İstanbul, 1993.

Osmanlı Belgelerinde Birinci Dünya Harbi, Başbakanlık Devlet Arşivi Genel Müdürlüğü Yayınları, İstanbul, 2013.

Özalp, Kâzım, Millî Mücadele 1919-1922, TTK. Yayınları, Ankara, 1972.

Öztürk, Cemil, “Mondros Mütarekesi”, D.İ.A., Cilt 30, İstanbul, 2005.

Ryan, Sir Andrew, Sonuncu Dragoman, (Çev: Dilek Berilgen Cenkçiler), TTK., Ankara, 2015.

Sarıhan, Zeki, Kurtuluş Savaşı Günlüğü I, TTK. Yayınları, Ankara, 1993.

Sertoğlu, Mithat, “Tarihimizde İlk Milli Kongre”, Belgelerle Türk Tarihi Dergisi., Sayı 21, Haziran-1969.

Shaw, Stanford, Birinci Dünya Savaşı ’nda Osmanlı Imparatorluğu Savaşa Giriş, Türk Tarih Kurumu Yayınları, Ankara, 2013.

Şahingöz, Mehmet, “Millî Mücadele'de Protesto ve Mitingler”, Türkler, Cilt XV, Yeni Türkiye Yayınları, Ankara, 2002.

Şapolyo, Enver Behnan, İstiklâl Savaşı Edebiyatı Tarihi Nesirler ve Şiirler (Milli Mücadelenin Edebi Vesikaları) 1919-1923, Ak Kitabevi, İstanbul, 1968.

Şapolyo, Enver Behnan, İstiklal Savaşı Edebiyatı Tarihi, Ak Kitapevi, İstanbul, 1967.

Şimşir, Bilâl, Ingiliz Belgelerinde Atatürk (1919-1938), Cilt I (Nisan 1919-Mart 1920), TTK., Ankara, 1973.

Tanrı̈ver, Hamdullah Subhi, Dă̆ Yolu, Cilt I, (Hazırlayan: Fethi Tevetoğlu ), Kültür Bakanlığı Yayınları, Ankara, 2000. 
Tansel, Fevziye Abdullah, "Mehmet Emin Yurdakul'un Eserleri-1 Şiirler”, Türk Sazı, TTK., Ankara, 1989.

Tansel, Selahattin, Mondros'tan Mudanya 'ya Kadar, Cilt I, MEB. Yayınları, İstanbul, 1991.

Tartan, Hakan, Atatürk'ün İzmir'i, TÜLOV Yayınları, İzmir, 2001.

Yazıcı, Nurcan, “On dokuzuncu Yüzyılda Sultanahmet Meydanı”, İdealkent, Sayı 2, Aralık 2010.

Yıldırım, Nahit, Constatinopolis Hipodromu, (Basılmamış Yüksek Lisans Tezi), Selçuk Üniversitesi Sosyal Bilimler Enstitüsü, Konya-2013.

Yıldız, Aybike, Tarihsel Birikime Sahip Kentsel Açık Alanların Dinamizmi - İstanbul Kent Örneği; Beyazıt Meydanı, Sultanahmet Meydanı Ve Taksim Meydanı, (Basılmamış Yüksek Lisans Tezi), İstanbul Üniversitesi Fen Bilimleri Enstitüsü, Aralık 2007. 